\title{
Information demands from families of children with Autism Spectrum Disorder
}

\author{
Demandas de informações das famílias de crianças com Transtorno do Espectro Autista \\ Demandas de información de las familias de niños con Trastorno del Espectro Autista
}

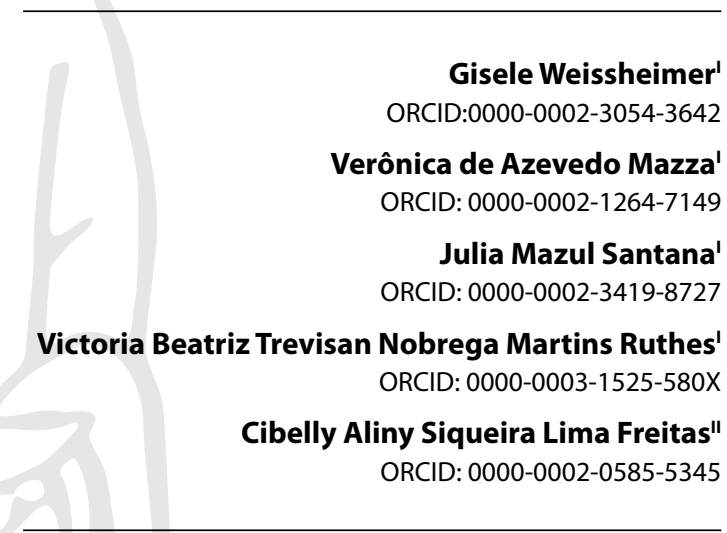

'Universidade Federal do Paraná. Curitiba, Paraná, Brazil. "Universidade Estadual Vale do Acaraú. Sobral, Ceará, Brazil.

How to cite this article: Weissheimer G, Mazza VA, Santana JM, Ruthes VBTNM Freitas CASL. Information demands from families of children with Autism Spectrum Disorder. Rev Bras Enferm. 2021;74(5):e20200642. https://doi.org/10.1590/0034-7167-2020-0642

\section{Corresponding author:}

Gisele Weissheimer

E-mail: gisele.weissheimer@gmail.com

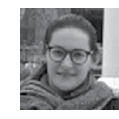

EDITOR IN CHIEF: Antonio José de Almeida Filho ASSOCIATE EDITOR: Mitzy Reichembach

Submission: $08-12-2020$

Approval: $12-01-2020$

\begin{abstract}
Objective: to identify the information demands of families of children with Autism Spectrum Disorder. Method: this is a qualitative study conducted through semi-structured and audiorecorded interviews with 55 family members, in the states of Paraná, Ceará, and Macapá between September 2018 and September 2019. Thematic category analysis and Qualitative Data Analysis Software resources were used for data organization. Results: it was identified that families need information regarding the characteristics of Autism Spectrum Disorder (definition, cause, possibility of cure, prognosis and the probability of having another child with Autism Spectrum Disorder); child's routine and behavior; future rights and expectations. Final considerations: information demands are relevant to support professionals, health managers and other services in health care organization to support families of children with autism. Descriptors: Autism Spectrum Disorder; Information; Family; Child; Social Support.
\end{abstract}

\section{RESUMO}

Objetivo: identificar as demandas de informações das famílias de crianças com Transtorno do Espectro Autista. Método: estudo qualitativo, realizado por meio de entrevista semiestruturada e audiogravada com 55 familiares, nos estados do Paraná, Ceará e Macapá, entre setembro de 2018 e setembro de 2019. Utilizaram-se análise categorial temática e os recursos do Qualitative Data Analysis Software para organização dos dados. Resultados: identificou-se que as famílias necessitam de informações referentes às características do Transtorno do Espectro Autista (definição, causa, possibilidade de cura, prognóstico e a probabilidade de ter outro filho com Transtorno do Espectro Autista); a rotina e o comportamento da criança; os direitos e as expectativas futuras. Considerações finais: as demandas de informação são relevantes para subsidiar os profissionais, gestores de saúde e de outros serviços na organização da atenção à saúde para apoiar as famílias de crianças com autismo.

Descritores: Transtorno do Espectro Autista; Informações; Família; Criança; Apoio Social.

\section{RESUMEN}

Objetivo: identificar las demandas de información de las familias de niños con Trastorno del Espectro Autista. Método: estudio cualitativo, realizado a través de entrevistas semiestructuradas y grabadas en audio con 55 familiares, en los estados de Paraná, Ceará y Macapá, entre septiembre de 2018 y septiembre de 2019. Se utilizaron recursos del Qualitative Data Analysis Software y análisis categórico temático para organizar los datos. Resultados: se identificó que las familias necesitan información sobre las características del Trastorno del Espectro Autista (definición, causa, posibilidad de curación, pronóstico y probabilidad de tener otro hijo con Trastorno del Espectro Autista); la rutina y el comportamiento del niño; derechos y expectativas futuras. Consideraciones finales: las demandas de información son relevantes para apoyar a los profesionales, gestores de salud y otros servicios en la organización de la atención de salud para apoyar a las familias de niños con autismo.

Descriptores: Trastorno del Espectro Autista; Acceso a la Información; Familia; Niño; Apoyo Social. 


\section{INTRODUCTION}

Epidemiological data have shown that one in 54 eight-year-old children has Autism Spectrum Disorder (ASD) ${ }^{(1)}$. ASD is characterized by changes in infant brain development that occur in the first years of life, mainly affecting communication, relationship/ interaction with people and behavior ${ }^{(2)}$. Children with ASD present a group of clinical signs, generating a new living condition for the family due to the need to manage children's needs ${ }^{(3)}$.

Faced with the challenges after the ASD diagnosis, the family seeks information about the health care network, professionals with experience in caring for children with the disorder, service providers that provide intervention/therapies ${ }^{(4)}$, support networks, social services, among others ${ }^{(5)}$. Access to information about the disorder, treatments and services and health care network can help families of children with ASD in coping with this new situation.

The provision of information to families is essential to ensure the proper long-term management the disease and assist in making decisions about necessary treatments/therapies. This enables them to actively participate in children's therapy, chosen together with a professional team ${ }^{(4)}$. Thus, support for these families has been the focus of several professionals, institutions, and policies ${ }^{(3-5)}$.

Despite this, it is still frequent to report families having difficulty receiving information, as this support is perceived as restricted ${ }^{(4)}$. There is dissatisfaction with the information received from health professionals, especially during the diagnosis period. Communication barriers are referred to, such as the use of medical jargon, insufficient, inaccurate information and little opportunity for discussion ${ }^{(6)}$.

Brazilian studies have addressed that, in the family experience, there is an information deficit ${ }^{(7-8)}$; however, this fact has not been explored in relation to the type of information required. Considering this scenario, this study aimed to identify the information demands of families of children with ASD. This study can assist professionals, institutions and managers in the organization of information support, supporting them in decision-making regarding caring for a person with ASD.

\section{OBJECTIVE}

To identify the information demands of families of children with Autism Spectrum Disorder.

\section{METHOD}

\section{Ethical aspects}

The research was conducted in accordance with the standards recommended by Resolution 466/12 of the Brazilian National Health Council (Conselho Nacional de Saúde), approved by a Research Ethics Committee, with opinion in favor of conducting the research. To ensure the confidentiality of all participants, we used the following encoding: acronym of the state where the research was conducted, followed by the sequential number of the interview.

\section{Type of study}

This is a descriptive research with qualitative approach. The Consolidated Criteria for Reporting a Qualitative Research (COREQ) was used according to applicability.

\section{Methodological procedures}

Fifty-five relatives of children with ASD participated in the study. The inclusion criteria were: 1) family of children aged four to ten years; 2) living in the same house; 3 ) caring for their child. The selection of these criteria is justified for the following reasons: first, the child's age was taken into account due to the period in which diagnosis commonly occurs and delimitation of ten years to include only relatives of children, since the focus in this study was not on families of adolescents.

As a second criterion, the family experience in the coexistence of care was considered, allowing participants to contribute to the objective of this study. The exclusion criterion used was being a minor. There was refusal of participation by six family members in Ceará and one in Paraná. There was no withdrawal of participation.

\section{Study setting}

The research was conducted in health and educational care institutions in three cities in different states, 21 interviews in Paraná - five in an Association of Parents and Friends of The Exceptional (APAE - Associação de Pais e Amigos dos Excepcionais) and 16 in a Center for Pediatric Neurology; 22 in Ceará, six in an APAE, two in a Psychosocial Care Center (Centro de Atenção Psicossocial) and 14 in a Rehabilitation Center; 12 in Amapá, in a Center for Early Childhood Education.

\section{Data source}

Data collection occurred through a one-to-one, semi-structured and audio-recorded interview with 55 family members. At each data collection site, the researchers knew the care flow to enable a personal invitation to the families. The sample was intentional and delimited by data saturation, i.e., when the objectives and understanding of the studied phenomenon are achieved.

\section{Data collection and organization}

The interviews were conducted between September 2018 and September 2019, guided by introductory questions about the information demands of families. Sociodemographic data were collected regarding family members (age, sex, years of study, kinship with child and family income) and children (age, sex and time of diagnosis of ASD). Two adaptations were made in the data collection guide after two pre-tests performed with family members in a collection center in Paraná. Such adaptations were made for the guide to present understandable language to the respondent.

The researchers who conducted the interviews in the three states are students of an undergraduate nursing course, nurses holding either a master's or doctoral degree. They were trained by a researcher/professor with experience in qualitative studies. The interviews, with average duration of 20 minutes, were 
recorded in audio through a digital recorder and transcribed in Microsoft Office Word ${ }^{\circ}$ format.

During the interview, participants were offered the possibility of receiving the transcribed interview; those who accepted, received them by e-mail or message from WhatsApp, according to preference. None of them requested a change in the content of the interview after reading.

\section{Data analysis}

The interviews were interpreted according to the thematic category analysis technique ${ }^{(9)}$. Data organization and preparation for analysis, reading of data and coding in chunks/text segments, groupings of text into categories were carried out, which were established based on similarity between the data found. The Qualitative Data Analysis Software was used to assist in data organization. The researcher interpreted the words and phrases of the interviews; from this, we used clippings of the registration units, constituting the codes, which were categorized.

Next, 275 codes originated in the interviews were analyzed, which were included in the categories as follows: 55 (20\%) represented the category characteristics of ASD; 98 (36\%), behavior children with ASD; 98 (36\%), rights of children with ASD; 24 (9\%), future of children with ASD.

\section{RESULTS}

Family members' characterization data showed a mean age of 37 years; $95 \%(n=52)$ were women; $15 \%(n=8)$ had five to eight years of study; $45 \%(n=25)$ were between nine and 11 years old; $38 \%(n=21)$ were between 12 and 16 years old; one person did not answer. Eighty-seven percent $(n=48)$ were the mothers; $5 \%$ $(n=3)$ were the fathers; $5 \%(n=3)$ the were grandparents; $2 \%$ $(n=1)$ were the sisters. Thirteen percent $(n=7)$ of families had incomes of up to $\mathrm{R} \$ 500.00$ (about 100 US dollars) (equivalent to $1 / 2$ minimum wage in 2020$) ; 35 \%(n=19)$ had $R \$ 1,001.00$ to $\mathrm{R} \$ 2,000.00$ (about 200 and 400 US dollars, respectively) (i.e., one to two minimum wages in 2020); $32 \%(n=18)$ reported income greater than $\mathrm{R} \$ 2,001.00$ (proportional to more than two minimum wages in 2020); a participant did not report.

In relation to children with ASD, the mean age was six years and $69 \%(n=38)$ were male. Thus, $27 \%(n=15)$ lived with ASD in a period of up to one year; $29 \%(n=16)$ were two to three years old; $25 \%(n=14)$ were four to five years old; $9 \%(n=5)$ were six to seven years old; $5 \%(n=3)$ did not know.

The following are thematic categories and subcategories as well as participants' statements. In the first category, referring to the characteristics of ASD, family members reported ignorance about ASD, its cause, signs and symptoms, the possibility of cure and the risk of having another child with the disorder.

At first, it was very difficult, I did not understand what ASD was, how to deal with autism, I was trying to inform myself, knowing how to handle it, how to understand it. (Ceará-1)

[...] because I did not know, did not quite understand what it was, what autism is and to this day I need to seek information and study so that I may come to understand and accept it. (Amapá-19)
[...] I just wanted to understand why she was born like this, because they said it's from my belly, I wanted to understand what happened in there. (Paraná-17)

We never know the cause, why children are born like this. (Ceará-9)

[...] the hospital was very negative for me, because he was born late, then I think it must have all caused the problem [autism]. (Amapá-3)

It was difficult because we could not define what was the child, what was age or disease, the syndrome. (Paraná-6)

I imagined I had a problem or difficulty in speech or lisp, I have never imagined that he would be autistic. (Amapá-13)

When he was born, I was already suspicious of his behavior. (Amapá-16)

[...] actually, we do not know if there is a cure or not. (Amapá-9)

I wonder if [ASD] has cure. (Ceará-12)

[...] [second child with autism] was already born, so I thought I wouldn't have this problem [autism], but it has nothing to do with. (Amapá-3)

In the second category, about the behavior of children with ASD, doubts about how to deal with children's behaviors involving communication were identified in participants' statements; the auditory, olfactory, integumentary sensory system; socialization; disruptive and stereotyped behavior.

[...] I would like some information on how to do at times of crises. (Paraná-1)

[...] I do not know what it was... it seems that he [child] got sick of his brother's voice; when his brother starts talking, he wants to assault him. (Amapá-2)

[...] there are times he feels pain, sometimes with more intensity, there are times that he does not feel pain, and this is something I have to learn about. (Ceará-2)

[...] she did not like to hear noise from blender, hairdryer. (Amapá-13)

Their sense of smell is much keener than ours. (Amapá-13)

If they take the bus, it's a bigger scandal, they don't like movement. She makes scandal, she beats herself, she bites, she wants to sit alone, no one can touch her. (Paraná-4)

I want to know how he [child] sleeps, how do I get him to go to sleep. (Ceará-9)

She could not stay in the seats, strangely, cried, threw herself to the ground. (Amapá-13)

[...] I wanted to know more how to take care of him, how to impose limits, what he can do and what he cannot do. (Paraná-21)

Because sometimes we don't know how to act... because we call and she does not answer and sometimes we have to scream, draw her attention. (Ceará-16) 
I [mother] would like so much to understand her [child], to find a way for her to live with other people. I go to people's house, she doesn't stop, she cries, beats, wants to leave, I can't leave the house with her. (Paraná-4)

I would like to understand why he is so young already having this part of active sexuality and I'm having a little difficulty dealing with it. (Paraná-11)

[...] he [child] is going from touching his intimate region to his teacher's. (Amapá-2)

In the third category, regarding the rights of children with ASD, several aspects were identified, such as lack of knowledge about what are the rights of a person with ASD; a reference on non-functionality of laws; coping with discrimination of society against the rights of children with ASD; on how to have access to the health and education rights of children with ASD; issues about how to access social rights, especially Continued Installment Benefits (BPC - Benefícios de Prestação Continuada), transportation vouchers and vacancy for the disabled.

I do not know the rights. (Ceará-16)

You have a right that I know, but every day is a fight, because what is in the Law is not guaranteed. (Amapá-13)

The Law is beautiful, wonderful, but in practice it does not work. (Amapá-13)

[...] I would like to know how to tell people what autism is. I know what autism is, but I cannot speak, I cannot explain to people. (Paraná-1)

[...] it is more we parents who have to be seeking more and more information. Informing us to try to improve living in society and in the family. (Paraná-18)

[...] I hear a lot "are you sure your child is autistic?", we don't like to hear that. One day I hope this will change. (Amapá-1)

Ineeded to stand in the priority line, they wanted to take me away by force. I had to show the report [of the child with ASD], Never been through this before. (Amapá-11)

[...] it will have to be by the Unified Health System (Sistema Único de Saúde). (Paraná-12)

Occupational therapists who assist are very few. (Amapá-13)

Depending on the problem we are going through, we do not receive help, we go to the consultation but do not get any help. (Amapá-2)

To tell you the truth, I don't know exactly, l even got his therapies... but thus I do not know his rights. (Amapá-12)

It is only the early stimulation here [name of public institution]. (Amapá-13)

Today she came to do speech therapy, she was evaluated and waits in the waiting line. (Amapá-13)
In fact, we have a lot of doubt about the benefit. (Paraná-14)

[...] [I would like to know] about the benefit [BPC], I really wanted to know, to get it, but you cannot have an income, like me, because if you have income, you cannot get. (Paraná-13)

I know you have many rights; I do not know how to speak directly what are they. (Amapá-11)

I do not know all [the rights], I believe I do not use because I do not know. (Amapá-5)

Now you got me, which I do not know [about the rights of the child]. (Ceará-3)

I would like to know the rights she has and I do not have access and do not see how. They say she is entitled to the vacancy of disabled, I do not know where to go to seek this right. (Ceará-21)

I did not know on this free pass issue, but the city always gave this support, because he did a lot of examination. (Ceará-2)

I know many rights [...] as the free pass, the subway card [...], half-entry in the movies, half an hour in the club of the stars, free pass in school bus, right to preference in many places, banks, lottery. (Ceará-6)

Both the companion and him [child] have care priority. (Paraná-21)

As l am a civil servant, l asked for my workload reduction. (Amapá-6)

The benefits I know are BPC, transportation voucher, the card. (Ceará-22)

They [professionals] passed all the information and since then we have searched there and he already has this right of exemption from shipping fare. (Paraná-16)

We have exemption from IPVA [vehicle tax]. We have been using it for three years. (Amapá-1)

He [child], right to airline tickets that have certain companies that accept, we fill out several forms with the physician's credential. (Amapá-2)

We already have his autism card from here in the state. (Amapá-6)

I really wanted to put her [child] in APAE, but I do not know how to do it, because there is never a vacancy in APAE. (Ceará-13)

[...] [lack] priority care at school. (Ceará-21)

At school, there is a law that guarantees a differentiated service, like an extra teacher, a companion. (Amapá-6)

In the fourth category, about the future of children with ASD, it is perceived that there is concern and hope in all statements regarding biological changes in children. Likewise, there is a future perspective on social development and independence. On the other hand, there is concern about who will care for the children in the absence of their parents. 
I expected, I have always expected that he would speak again. (Paraná-13)

We are trying to do our best to make he [child] develop. (Amapá-5)

I would like to know more to be able to help my daughter more, because sometimes we call for her and it is as if she had not listened to. (Ceará-8)

Sometimes I wonder if my son will learn to read, if he will ever come home and tell a situation that happened to him. (Ceará-2)

Who will help him if me and him are not around [father]. (Amapá-13)

Thus they can even work in the future, have their independence. (Paraná-18)

[...] I've seen on television that autistic children can be doctors, can autistic people be normal like a normal person? (Ceará-3)

\section{DISCUSSION}

During the ASD diagnosis process, questions arise about the disorder and other aspects involving children with this condition. This is a confusing and stressful time for families, as they are in the middle of something unknown ${ }^{(10)}$. In this context, professionals become essential to advise families on the necessary information. It is important that parents are aware of the characteristics and aspects that involve ASD, in order to focus on searching for resources for children ${ }^{(4)}$ and necessary interventions, depending on the different community contexts in which families live ${ }^{(11)}$. As in this study, in others, it is pointed out that families would like to know information involving children with $\mathrm{ASD}^{(12-13)}$. There is no specific treatment for the disorder so far, but there are several therapies that help promote child development ${ }^{(16)}$.There is research showing that ASD may be caused by genetic, environmental and/or adversity factors in the gestational period ${ }^{(14-17)}$.

Among identical twin siblings, the risk is 60 to $90 \%$; on the other hand, among non-identical twins, the chance is 0 to $30 \%$ risk for having the disorder ${ }^{(17)}$. In families with paternal siblings, the chances of occurrence increase by $23.34 \%$; in the case of families with maternal siblings, the chances increase by $28.32 \%$ in a second child. In firstdegree maternal cousins, the possibility is $13.79 \%$; in first-degree paternal cousins, the possibilities increase by $13.55 \%{ }^{(18)}$.

It is important that families receive information about ASD signals, which involve deficits in communication, social interaction, behavior, and sensory changes ${ }^{(19)}$. Behavior involves body movements, use of objects, and restricted or repetitive speeches ${ }^{(19)}$. Sensory interests can cause children to be attracted to certain aspects such as texture, smell, taste, vision and sounds, and not in the function of a particular object $^{(16-20)}$. Commonly, adhering to routines is inflexible; children may be interested in specific toys or objects, stay for long periods using the same toys or performing the same activity ${ }^{(19)}$.

The characteristics described above may cause children to present some different behaviors. For instance, hypersensitivity to sound can generate crises in the presence of loud sound/ noise. It is important for the family to understand what triggers disruptive behaviors ${ }^{(21)}$ and stereotyping ${ }^{(22)}$.

It is necessary to know how to deal with child anxiety, social ${ }^{(23)}$ and sensory skill development ${ }^{(21)}$, accompany children in their leisure activities ${ }^{(21-22)}$ and help them improve communication ${ }^{(21)}$. Moreover, they need to know how to help children in activities of daily living, such as rest, sleep, self-care ${ }^{(21)}$, and food ${ }^{(20)}$.

Children may have difficulty understanding facial expressions, so it is difficult to keep in memory an expression that is associated with a certain emotion. They are rigid in their learning style and may have difficulty transferring learning to other situations ${ }^{(16)}$. Knowing this information is important for those who care for children, because families commonly experience stressful situations because they cannot cope or understand child behavior ${ }^{(21-22)}$.

To meet children's demands of everyday life, families need information about rights, public policies, legislations ${ }^{(21)}$ and social subsidies $^{(24)}$ that can assist them. At first, it is essential to understand that, in Brazil, a person with ASD is considered, for legal purposes, disabled. Thus, they enjoy the rights of other people and those protected for disabled people, provided for in special laws.

People with disabilities are those who have long-term physical, mental, intellectual or sensory impairments, which, in interaction with one or more barriers, can obstruct their full and effective participation in society on equal terms with other people $\mathrm{e}^{(25)}$.

According to the literature and data of this research, families have doubts about how to access the health care network. This involves the need to obtain information about institutions that provide specific therapies or treatments ${ }^{(26)}$ and services for family counseling ${ }^{(12)}$. On the other hand, parents are often overwhelmed and confused by the amount of options for ASD treatments according to the research they carry out autonomously. Thus, they need services that instruct them ${ }^{(27)}$.

The legislation that regulates health promotion, protection and recovery, as well as organization and functioning of health services in Brazil, consists of Law 8,080 of September 19, $1990^{(28)}$. Recently, Law 13,146 of July 6, 2015 reinforces some rights to the health of people with disabilities ${ }^{(25)}$, while Law 12,764 of December 27, 2012 reaffirms the right to health for people with ASD from diagnosis to rehabilitation with specialized services ${ }^{(29)}$.

The Guidelines for Attention to the Rehabilitation of People with ASD provide for monitoring by a specialized center ${ }^{(3)}$. This guideline establishes individualized service. The health team articulates with the social and support network such as social assistance services or others that can help children and their family. Such articulations also involve referrals to the education network ${ }^{(3)}$.

Educational resources are important ${ }^{(23)}$ and parents need to know about the special educational programs available that are suitable for their children ${ }^{(12)}$. Law 13,146 , of July 6,2015 , establishes the rights to education and vocational training for people with disabilities ${ }^{(25)}$. Education is a right guaranteed at all levels of learning throughout life, in order to achieve the maximum development of their talents and physical, sensory, intellectual and social skills according to their characteristics, interests, and learning needs.

People with ASD are guaranteed social assistance by the Federal Constitution of 1988, Organic Law on Social Assistance ${ }^{(30)}$. There are social programs and benefits for low-income families and others specific to people with disabilities. This often raises doubts, because people are unable to access some benefits because they are not classified as low-income. Such benefits are: Bolsa Família, Minha Casa Minha Vida, Telefone Popular, exemption from payment of 
registration fees in public tenders, interstate free pass, fee exemption for municipal urban transport ${ }^{(31)}$, BPC, among others.

The specific rights for people with disabilities are: exemption of Tax on Manufactured Products (IPI); exemption of Tax on Financial Operations (IOF); exemption of Tax on the Circulation of Goods and on Services of Interstate and Intermunicipal Transportation and Communication (ICMS); exemption of Tax on Property of MotorVehicles (IPVA).

Additionally, disabled people have the right to housing, including protected residence and priority in home ownership ${ }^{(25)}$; discount on companion airfare ${ }^{(32)}$; identity card with ASD symbol ${ }^{(33-34)}$; priority in service lines ${ }^{(25)}$; seats reserved for public transportation for people with disabilities ${ }^{(35)}$; preference in parking lot; priority in receiving income tax refunds; priority in the procedural process, judicial and administrative procedures in which they are a party or interested in all acts and diligences ${ }^{(25)}$.

It is important to know the rights. Thus, professionals who assist these families are essential for guidance and indication of where and how to get them. In addition to the rights mentioned above, physical and moral integrity and the right to free development of the personality are provided by Law as well as for anyone in society ${ }^{(29)}$. In line with this, ASD awareness campaigns can help society to better understand this disorder.

Many families receive negative comments from people in the community when children have a bad mood or present stereotypes in a public place ${ }^{(2)}$. In this research, participants reported that they would like to know strategies that would help them to explain the disorder to other people and that would promote awareness and integration of the community in relation to ASD. It was observed that social acceptance and support from family, friends and community are considered important aspects for parents of children with ASD ${ }^{(21)}$, as many still suffer prejudice.

One of the families' perspectives is in relation to children's acceptance in society about issues related to work, employment, profession and their independence ${ }^{(36-37)}$. They express expectations about the possibility of taking a higher education course ${ }^{(38)}$ and having independence ${ }^{(39)}$.

A study assessed the general long-term characteristics of people with ASD in relation to work and independence. In this research, 15 studies conducted in the United Kingdom, Scandinavia, North America and Japan were analyzed, involving 828 people with ASD, who were followed from childhood to adolescence or adulthood ${ }^{(40)}$.

Such characteristics were classified as follows: "good", in 19.7\% of people, indicating that they were able to work, but required some support in daily life; "Intermediate", in 31.1\%, denoting that they had some degree of independence and although they demanded support and supervision, they did not need specialized support for care at home; "Bad" or "very bad", in $47.7 \%$ of people, i.e., requiring special supervision, high-level support at home or high-level hospital care ${ }^{(40)}$. As difficult as it may be, many families need to set aside much of their expectations for their child and keep the future in mind as children grow and develop ${ }^{(16)}$.

Children's prognosis is not limited, it depends on the characteristics of each individual. In a study carried out in Italy with 110 parents/relatives of people with ASD - ranging from 8.1 to 28 years old (average of 20.6 years old) - 83 participants were male and 27 female, being able to check some aspects related to the prognosis. The signs/symptoms improved in $81.5 \%$ of cases. In $10.9 \%$, it was found that there was no change, and in $7.6 \%$, symptoms worsened. Verbal communication was present in $66 \%$, absent in $15.1 \%$; in $18.9 \%$, an ability to imitate and gesture communication was perceived ${ }^{(39)}$.

Sensory perception skills changed in $30.2 \%$, improved in $58.8 \%$ and worsened in $11 \%$ of cases. Among the symptoms, $72.2 \%$ had delayed or lack of language; $48.9 \%$ had stereotypes; $43.3 \%$ had attention deficit; $41.1 \%$ had behavioral disorders such as aggression; $30 \%$ were in social isolation; $20 \%$ had sleep disorders; $13.3 \%$ had eating problems. Epileptic seizures occurred in $28.9 \%$ (31 people) ${ }^{(39)}$.

There are policies that establish some of the aspects mentioned by families with regard to ensuring the insertion of these people in society in relation to study, work, employment and guaranteeing their rights ${ }^{(25)}$. Therefore, it is important that families are educated to seek the rights of children and exercise children's independence for the future. Despite the resources, many families need more support to know how to access and seek available services, in order to promote a satisfactory prognosis and children's independence ${ }^{(41-42)}$.

In addition to knowing the rights, it is important that families know how to seek them when they are not accessible. It is verified that there are precarious organizational and operational structures for obtaining health, education and labor market services in relation to what the Law determines. Law making is not enough to effectively guarantee the rights of families ${ }^{(8,43)}$. Despite this, it is essential that families are educated and that, in the absence of rights, seek the respective state/municipal resources to obtain them ${ }^{(8,43)}$. The social participation of people with disabilities in decision-making processes related to policies is still fragile, and it is extremely important that families empower themselves for participation and social control, with a view to effective access to their rights ${ }^{(44)}$.

\section{Study limitations}

In this study, families' information needs were raised, but there was no classification of information demands according to the time elapsed after the diagnosis. It is suggested that this time may demonstrate differences in information needs. Thus, it is considered that future studies can explore this issue.

\section{Contributions to nursing, health, and public policies}

Access to safe and reliable information is essential so that families can manage children's needs, leaving it to professionals, health managers and other areas to provide assistance so that these needs are met.

\section{FINAL CONSIDERATIONS}

Family's demands for information are relevant to support professionals, health managers and other services in the organization of health, social and educational care to support families of children with ASD.

\section{FUNDING}

This study was financed by the Brazilian National Council for Scientific and Technological Development, Ministry of Technology, Science and Information with resources obtained by the Universal Project approved by the MCTI/CNPq 01/2016 call. 


\section{REFERENCES}

1. Maenner MJ, Shaw KA, Eds JB, Washington A, Patrick M, DiRienzo M, et al. Prevalence of autism spectrum disorder among children aged 8 years: autism and developmental disabilities monitoring network, 11 Sites, United States, 2016. MMWR Surveill Summ. 2020;69(4):1-12. https://doi.org/10.15585/mmwr.ss6904a1

2. Whitmann TL. O desenvolvimento do autismo social, cognitivo, linguístico, sensório-motor e perspectivas biológicas. São Paulo (SP): M. Books do Brasil; 2015.

3. Ministério da Saúde (BR). Secretaria de Atenção à Saúde. Departamento de Ações Programáticas Estratégicas. Diretrizes de Atenção à Reabilitação da Pessoa com Transtornos do Espectro do Autismo (TEA). Brasília: Ministério da Saúde; 2014: 86 p.

4. Edwards AG, Brebner CM, McCormack PF, MacDougall CJ. From 'parent' to 'expert': how parents of children with autism spectrum disorder make decisions about which intervention approaches to access. J Autism Dev Disord. 2018;48(6):2122-38. https://doi.org/10.1007/ s10803-018-3473-5

5. Liu Y, Fisher K. Engaging with disability services: experiences of families from Chinese backgrounds in Sydney. Aust Soc Work. 2017;70(4):441-52. https://doi.org/10.1080/0312407X.2017.1324885

6. Smith J, Cheater F, Bekker H. Parents' experiences of living with a child with a long-term condition: a rapid structured review of the literature. Health Expect. 2015;18(4):452-74. https://doi.org/10.1111/hex.12040

7. Maia Filho ALM, Nogueira LANM, Silva KCO, Santiago RF. A importância da família no cuidado da criança autista. Rev Saúde Foco [Internet]. 2016[cited 2020 Aug 02];3(1):66-83. Available from: http://www4.unifsa.com.br/revista/index.php/saudeemfoco/article/view/719

8. Gomes PT, Lima LH, Bueno MK, Araújo LA, Souza NM. Autism in Brazil: a systematic review of family challenges and coping strategies. $J$ Pediat. 2015;9(2):111-21. https://doi.org/10.1016/j.jpedp.2015.01.005

9. Bardin L. Análise de conteúdo. 4. ed. Lisboa: Edições70; 2010. 225 p.

10. Rivard M, Millau M, Magnan C, Mello C, Boulé M. Snakes and ladders: barriers and facilitators experienced by immigrant families when accessing an autism spectrum disorder diagnosis. J Dev Phys Disabil. 2019;31:519-39. https://doi.org/10.1007/s10882-018-9653-6

11. Pickard K, Rowless S, Ingersoll B. Understanding the impact of adaptations to a parent-mediated intervention on parents' ratings of perceived barriers, program attributes, and intent to use. Autism. 2019;23(2):338-49. https://doi.org/10.1177/1362361317744078

12. Tait K, Hu FFA, Sweller N, Wang W. Understanding Hong Kong Chinese families' experiences of an autism/ASD diagnosis. J Autism Dev Disord. 2016;46(4):1164-83. https://doi.org/10.1007/s10803-015-2650-z

13. Dinora $P$, Bogenschutz $M$. Narratives on the factors that influence family decision making for young children with autism spectrum disorder. J Early Interv. 2018:40(3):195-211. https://doi.org/10.1177/1053815118760313

14. Lyall K, Croen L, Daniels J, Fallin MD, Ladd-Acosta C, Lee BK, et al. The changing epidemiology of autism spectrum disorders. Annu Rev Public Health. 2017;38:81-102. https://doi.org/10.1146/annurev-publhealth-031816-044318

15. Amaral DG. Examining the causes of autism. Cerebrum; 2017:01-17.

16. Williams C, Wright B. Convivendo com autismo e síndrome de Asperger: estratégias práticas para pais e profissionais. São Paulo: M. Books do Brasil; 2008.

17. Tick B, Bolton P, Happé F, Rutter M, Rijsdijk F. Heritability of autism spectrum disorders: a meta-analysis of twin studies. J Child Psychol Psychiatry. 2016:57(5):585-95. https://doi.org/10.1111/jcpp.12499

18. Yip BHK, Bai D, Mahjani B, Klei L, Pawitan Y, Hultman CM, et al. Heritable variation, with little or no maternal effect, accounts for recurrence risk to autism spectrum disorder in Sweden. Biol Psychiatry. 2018;83(7):589-97. https://doi.org/10.1016/j.biopsych.2017.09.007

19. American Psychiatric Association. DSM-5: Manual diagnóstico e estatístico de transtornos mentais. Porto Alegre: Artmed Editora; 2014. 99 p.

20. Curtiss SL, Ebata AT. The nature of family meals: a new vision of families of children with autism. J Autism Dev Disord. 2019;49(2):441-52. https://doi.org/10.1007/s10803-018-3720-9

21. Preece D, Symeou L, Stosic J, Troshanska J, Mavrou K, Theodorou E. Accessing parental perspectives to inform the development of parent training in autism in south-eastern Europe. Eur J Spec Needs Educ. 2016;32(2):252-69. https://doi.org/10.1080/08856257.2016.1223399

22. Park HI, Park HY, Yoo E, Han A. Impact of Family-Centered Early Intervention in Infants with Autism Spectrum Disorder: A Single-Subject Design. Occup Ther Int. 2020 Mar; 2020:1-7. DOI: 10.1155/2020/1427169

23. Derguy C, Michel G, M'bailara K, Roux S, Bouvard M. Assessing needs in parents of children with autism spectrum disorder: a crucial preliminary step to target relevant issues for support programs. Intellect Dev Disabil. 2015;40(2):156-66. https://doi.org/10.3109/13668250. 2015.1023707

24. Hennel S, Coates C, Symeonides C, Gulenc A, Smith L, Price AMH, et al. Diagnosing autism: contemporaneous surveys of parent needs and paediatric practice. J Paediatr Child Health. 2016;52(5):506-11. https://doi.org/10.1111/jpc.13157

25. Presidência da República (BR). Lei n. 13.146, de 6 de Julho de 2015. Institui a Lei Brasileira de Inclusão da Pessoa com Deficiência (Estatuto da Pessoa com Deficiência). Diário Oficial da República Federativa do Brasil, Brasília, 2015. 
26. Frye L. Fathers' experience with autism spectrum disorder: Nursing implications. J Pediatr Health Care. 2016;30(5):453-63. https://doi. org/10.1016/j.pedhc.2015.10.012

27. Frame KN, Casey LB. Variables influencing parental treatment selection for children with autism spectrum disorder. Child Youth Serv Rev, Elsevier. 2019;106:104464. https://doi.org/10.1016/j.childyouth.2019.104464

28. Presidência da República (BR). Lei n. 8.080, de 19 de Setembro de 1990. Dispõe sobre as condições para a promoção, proteção e recuperação da saúde, a organização e o funcionamento dos serviços correspondentes e dá outras providências. Diário Oficial da União, Brasília, 1990.

29. Presidência da República (BR). Lei n. 12.764, de 27 de Dezembro de 2012. Institui a Política Nacional de Proteção dos Direitos da Pessoa com Transtorno do Espectro Autista. Diário Oficial da União, Brasília, 2012.

30. Presidência da República (BR). Lei n. 8.742, de 7 de Setembro de 1993. Lei orgânica da assistência social. Dispõe sobre a organização da Assistência Social e dá outras providências. Diário Oficial da União, Brasília, 1993.

31. Ministério do Desenvolvimento Social (BR). Assistência social. Serviços e programas. Governo Federal. 2020.

32. Presidência da República (BR). Resolução n. 280, de 11 de Julho de 2013. Dispõe sobre os procedimentos relativos à acessibilidade de passageiros com necessidade de assistência especial ao transporte aéreo e dá outras providências. Diário Oficial da União, Brasília, 2013.

33. Presidência da República (BR). Lei n. 7.116, de 29 de Agosto de 1983. Assegura validade nacional as Carteiras de Identidade regula sua expedição e dá outras providências. Diário Oficial da União, Brasília, 1983.

34. Presidência da República (BR). Decreto n. 9.278, de 05 de Fevereiro de 2018. Regulamenta a Lei n 7.116, de 29 de agosto de 1983, que assegura validade nacional às Carteiras de Identidade e regula sua expedição. Diário Oficial da União, Brasília, 2018.

35. Presidência da República (BR). Lei n. 10.048, de 08 de Novembro de 2000. Dá prioridade de atendimento às pessoas que especifica, e dá outras providências. Diário Oficial da União, Brasília, 2000.

36. Grant N, Rodger S, Hoffmann T. Intervention decision-making processes and information preferences of parents of children with autism spectrum disorders. Child Care Health Dev. 2016 Jan;42(1):125-134. DOI: 10.1111/cch.12296

37. Blauth LK. Improving mental health in families with autistic children: benefits of using video feedback in parent counselling sessions offered alongside music therapy. Health Psychol Rev. 201;5(2):138-150. https://doi.org/10.5114/hpr.2017.63558

38. Kocabiyik OO, Fazlioğlu Y. Life stories of parents with autistic children. Educ. Train. 2018 Feb;6(3):26-37 https://doi.org/10.11114/jets. v6i3.2920

39. Operto FF, Martino F, Rinaldi A, Cerracchio A, Salvati G, Orza M, et al. Long-term outcome of autistic spectrum disorder: a retrospective case study in a southern italian region. Riv Ital Pediatr. 2017:43(83). https://doi.org/10.1186/s13052-017-0399-z

40. Steinhausen $\mathrm{HC}$, Jensen $\mathrm{CM}$, Lauritsen MB. A systematic review and meta-analysis of the long-term overall outcome of autismo spectrum disorders in adolescence and adulthood. Acta Psychiatr Scand. 2016:133(6):445-452. https://doi.org/10.1111/acps.12559

41. Pearson JN, Traficante AL, Denny LM, Malone K, Codd E. Meeting FACES: preliminary findings from a community workshop for minority parents of children with autism in Central North Carolina. J Autism Dev Disord. 2020;50(1):1-11. https://doi.org/10.1007/ s10803-019-04295-4

42. Alenazi DS, Hammad SM, Mohamed AE. Effect of autism on parental quality of life in Arar city, Saudi Arabia. J Family Community Med. 2020;27(1):15-22. https://doi.org/10.4103/jfcm.JFCM_157_19

43. Neves-Silva P, Prais FG, Silveira AM. The inclusion of disabled persons in the labor market in Belo Horizonte, Brazil: scenario and perspective. Ciênc Saúde Coletiva. 2015;20(8):2549-58. https://doi.org/10.1590/1413-81232015208.17802014

44. Silva ACC, Oliver FC. Disabled persons on the way to participatory democracy. Cad Bras Ter Ocup. 2019;27(2):279-92. https://doi. org/10.4322/2526-8910.ctoao1604 